\title{
Problems and Countermeasures of Civil Servants at the Grass-roots
}

\section{Level}

\author{
Ping Zhang \\ College of administrative management major, North China Electric Power University, Beijing, \\ 102206, China
}

Keywords: Government, Servants at the grass-roots level, Problems and countermeasures, Laws and regulations

\begin{abstract}
There are huge number of civil servants sticking to the first line, and they directly contact with the masses and responsible for the administrative management and service. It's extremely important for government to improve the ability of government public administration to improve quality of the team. Nowadays, there are a lot of problems of Grass-roots civil servants management, which should be solved urgently. Then we advance some specific countermeasures.
\end{abstract}

\section{Introduction}

We all know there are a lot of problems of Grass-roots civil servants management. This article will explain what are the problem of civil servants at the grass-roots level. After understanding the problem, I will put forward some countermeasures from different standpoints. First of all, the government needs to further perfect civil servants at the grass-roots level management laws and regulations. Secondly, to properly increase the number of civil servants in less developed areas. Thirdly, we will further improve the civil servants at the grass-roots level training institutions and mechanisms. Fourthly, the government should establish and improve a more scientific and standard mechanism of grass-roots civil service examination system. Fifthly, the government must strengthen the perfect management system, and expand the civil servant's promotion space. Sixthly, the government should further strengthen the supervision and inspection of civil servants at the grass-roots level.

There are huge number of civil servants, who stick to the first line, directly contact with the masses and responsible for the administrative management and service. It's extremely important for government to improve the ability of government public administration to improve quality of the team. Nowadays, there are a lot of problems of Grass-roots civil servants management, which should be solved urgently. Refers to the grass-roots civil servants in various tissues in the lowest layer, direct contact with the masses, in performing their duties according to law, into national administrative establishment, burden salary welfare by national finance. The following three problems in civil servants at the grass-roots level:

Above all, demand is big, grass-roots civil servants are in short supply, which cause many problems.

The large number of civil servants is on the rise. Civil servants at the grass-roots level accounted for $60 \%[1]$,but The number of civil servants are assigned to many areas at the grass-roots level, county, township and the street, and a regional distribution to the number of people are rare, which leads to the stress of civil servants at the grass-roots level and the decrease of the quality of the work of public servants. According to Ministry of Human Resources and 
Social Security of the People's Republic of China, in 2008, 2010 and 2009, the national civil service number respectively is 6.597 million people, 6.789 million people and 6.789 million people[2]. At the end of 2012 the total number of civil servants has amounted to 7.089 million people.

Grassroots workload directly service to the citizens is big, a limited number of civil servants at the grass-roots level is often difficult to deal with. Matter more than less, results in the decrease of grass-roots civil servants work quality, their pressure is high. According to the survey, Puming police station in Shanxi with a total of 15 civil servants, but they need to sever more than ten thousand people. [3]These civil servants need to deal with the case, the household registration management, logistics, etc. One person is responsible for each job. If a citizen want to deal with a business, requiring to handle the business of civil servants work on. If the civil servant didn't go to work, or sick leave, the business will not be able to deal with. Of course, if the masses demand to quickly deal with business, civil servants have to go to work. A number of civil servants must to serve so many people, making the job boring directly. They affect the quality of civil servant's job.[4]

Due to the civil servants at the grass-roots level in short supply, many local governments employ a large number of temporary worker to solve the staff shortage, whose responsibility consciousness is poor and bound is smaller. To reduce the government's work quality is inevitable, and there are many harm the image of the government office. For example, there is some civil servant's attack in some areas.

Secondly, civil servants incentive mechanism has many shortcomings. Leading to civil servants work enthusiasm is low. For example, the fuzzy evaluation index, the single evaluation subject and evaluation methods.[5]

The civil service examination content is divided into the civil service act virtue, ability, diligence, performance and integrity.But it is not a clear definition of the five kinds of assessment indexes,which is difficult to quantify assessment, and easy to distortion.

Appraisal main body for the management department of civil servants authority and the appraisal committee, and citizens don't participate, according the civil service examination (try out). To a certain extent, the authenticity of the evaluation model of impact assessment results.

Annual examination is the main way of evaluation and daily examination is very little, leading to the decrease of assessment of the reliability and validity. Light on the appraisal method, Attaches great importance to the qualitative assessment, despise the quantitative assessment, it will also affect the reliability and validity of assessment results.

Thirdly, there are relatively imperfect laws and regulations construction about civil servants at the grass-roots level in less developed areas,despite introducing the civil servant law or regulations in China and in some areas.So far, involving the classification and grading management of grass-roots civil servants law has not been promulgated. And the regulation has more disadvantages of the law.

Due to low degree of development in less developed areas, some of the regulations adjusting measures to local conditions should be adapted to the region. However, most of the less developed areas have not to do so.[6]

\section{Civil servants in less developed areas need to train urgently to improve the ability to work.}

For historical reasons, degree of more than 50 of the civil servants mostly is poor, most of them graduated from junior high school will take the place of the parents. Many of the younger civil servants hired not through formal orientation of the civil service exam. In recent years, the 
grass-roots civil servants employed mechanism continuously perfect, Civil servants at the grass-roots level is through formal state examination are employed, but the civil servants of being employed graduate from college soon who have no work experience.

Now, for leadership training than for ordinary staff training, Civil servants at the grass-roots level training content too much emphasis on the universal, and lack of pertinence.[7] The government emphasis on politics theoretical study and ignore the economic management knowledge learning. The government attaches great importance to the theoretical knowledge training, ignoring the professional technical knowledge and ability training. In a word, the government's training can't work well for the actual service.

Training methods don not adapt to the development of the society. Civil servants at the grass-roots level training methods mainly focus on training, more political theory training to all levels of party and administrative institutions. Training is mainly face-to-face teaching, seldom practice drills. The government's training is rarely used free discussion and simulation model.

The government's training results often are not subject to the examination, many government departments have the training as a holiday.[8]Training purpose changed, became a way to relieve the stress of work. The result of the training evaluation is more elaborate.

Fifthly, civil servants incentive mechanism is not perfect. Fewer opportunities for advancement and promotion space are the main reason for the civil service to promote and income increase. Our country civil servants promotion management exist many problems.

Although our government gradually increased the proportion of the selection and hiring of grass-roots civil servants, this does not solve the most grass-roots civil servants, especially a large number of villages and towns clerk's promotion. Many grassroots work experience's outstanding public servants are still not selected to the high level of party and government organs. Although immediate county authority can be promoted to section head of non-leadership duty officials, the current promotion channel is always in the semi-closed state. This seriously affects and dampened some silently in there for many years the work enthusiasm of civil servants at the grass-roots level.

Usually officials of non-leadership categories worked in the central organs and provincial authorities in theory can be promoted to the highest level of non-leadership categories. Officials worked in the municipal authority's highest level can be promoted to researcher.

Officials of non-leadership duty worked of the highest in the county authority can be promoted to section head, or officials worked in the villages and town government's promotion .The regulations have been made. This compression even closed the town level authority from the system's promotion space of non-leadership duty officials.

Sixthly, the supervision of civil servants at the grass-roots level have influenced by interpersonal shutdown in less developed areas. Most civil servants are indigene, and doing something not by the articles of association, but by a face. It is called as "shualian"in Chinese. Ordinary people who have nothing to do with civil servants do business are very difficult. This is form of bureaucratic thought for a long time. Civil servants don not get into the habit of working in accordance with the rules.

\section{The following are some specific countermeasures:}

First of all, the government needs to further perfect civil servants at the grass-roots level management laws and regulations.

We should explore China's civil servants at the grass-roots level classification, classification management standard laws and regulations, to make more legalized, standardized and scientific management of grass-roots civil servants. We need to draw lessons from and absorb foreign 
advanced technology and experience of the civil servant management on the basis of the existing civil service laws and regulations. Of course, we will base on China's national conditions.

Government departments should establish the laws and regulations of the township promotion of non-leadership duty officials as soon as possible to make up for the shortcomings of the existing law. Fierce grassroots public service and training mechanisms need to formulate relevant laws. The number of civil servants, and quality should also have certain rules.

Government should expand grass-roots civil servants promotion space and increase the chance of promotion by setting, modifying and perfecting the relevant laws and regulations.

Secondly, to properly increase the number of civil servants in less developed areas. Now, because of the fiscal expenditure rising, civil servants cann't be hired as needed. However, the state should plan distribution of public servants to ensure the number of the nearest grassroots public meet demand. Government should to ensure that each civil servants have their own work and avoid bloated.

Developing a more scientific, standardized and unified standard of grass-roots civil servants employed is also the key.

Thirdly, we will further improve the civil servants at the grass-roots level training institutions and mechanisms. Increasing the chance of ordinary civil servants at the grass-roots level training is an important way. Superior departments should train civil servants at the grass-roots level directly contacting with the masses training a real demand of civil servants at the grass-roots level. Superior departments should train civil servants in less developed areas.

Adjusting the training content, training object properties and working characteristics are the key. We should combine theory study and practice of learning and training way need to change.

Moreover, for the purpose of training to improve the ability to work, everyone should pay attention to train when sent to training.

Superior departments should strengthen the assessment and management of training effect. We should formulate the relevant assessment standards, and track record. Superior departments should be examined for the actual work ability related training of civil servants at the grass-roots level and the performance evaluation on a regular basis.

Civil servants who can't finish the work tasksshould be punished. Civil servants punishment mechanism will keep improving. The government should do that reward and punishment should be clear for civil servants at the grass-roots level.[9]The government should establish strict and normative exit and elimination mechanism of public servants.

Fourthly, the government should establish and improve a more scientific and standard mechanism of grass-roots civil service examination system. We should pay attention to the assessment content and the operability of assessment index. The government should be law-abiding and actual performance as the main content of the assessment of civil servants at the grass-roots level in our country. Staff in the inspection should be combine qualitative and quantitative evaluation, quantitative evaluation as the main line to fundamentally change our country civil servants at the grass-roots level evaluation is too extensive, and the problems of fuzzy assessment index.

The government should implement diversity of grass-roots civil service examination, civil service examination should be fair, let common people's participate. Ordinary citizens have the right to participate in the evaluation of civil servants.

The government should optimize the grass-roots civil service examination way and should be guided by the modern enterprise management mode. The government should design the civil service jobs progress review and set up the quantitative evaluation index according to the specific 
jobs grass-roots civil servants. The government should allocate the annual and daily assessment in the evaluation of overall weight.

Fifthly, the government must strengthen the perfect management system, and expand the civil servant's promotion space. The government to formulate scientific and standardization of the grass-roots civil servants promotion standard is one important link. According to the integrated management at the grass-roots level, professional technical and administrative law enforcement different kinds and the characteristics of the regions, departments and professional fields,the government can make all kinds of promotion criteria.Strictly executing the promotion criteria is the most important.

Sixthly, the government should further strengthen the supervision and inspection of civil servants at the grass-roots level. National discipline inspection organs at all levels should further strengthen the discipline of civil servants at the grass-roots level supervision and inspection andset up effective internal supervision system. The majority of citizens and social groups should play to the supervision of the society from all walks of life right. The government should try to build a more powerful supervision system and the unblocked and convenient feedback mechanism. In short, internal supervision and external supervision jointly play a good role.

The government wants to better service for the majority of citizens, we must improve the quality of civil servants at the grass-roots level. In recent years, civil servants at the grass-roots level management reform,but there are still many problems. We must reflect on why. Policy must be strictly enforced, and it can not be optionally change.

Civil servants at the grass-roots level and higher level of civil servants properties are different. So the management of civil servants at the grass-roots level reform must seize its direct contact with the characteristics of ordinary citizens.

The reform of the civil servants at the grass-roots level is still a long way to go.

\section{Conclusion}

There are a lot of problems of Grass-roots civil servants management, and the government wants to better service for the majority of citizens, we must improve the quality of civil servants at the grass-roots level. Government will put forward some countermeasures from different standpoints, especially in laws and regulations.

\section{Reference}

[1]H. Bing, Civil Servants to Cultivate and Improve.[J] Comparative Economic \& Social Systems 2014 16(2):32-33

[2]X.F.Zhu, Y.qian,Civil Service Quality Survey.[J] Management World 2012 9(4):14-16

[3]M.Y.Shi, The Improvement of Quality of Civil Servants From the Perspective of Government.[M]Peking University Press

[4]G.Q.Zhang,Public Administration（Third Edition ） [M].

[5]M.Z.Xiao,HumanResoure Development and Management: Application to Public Organization(2and Edition)(In Chinese).[M]China Machine Press.

[6]W.C.Bao,Administrative Law Social Science.[M]CHINA PUBLISHING HOUSES (In Chinese)

[7]K.Z.Zhang,Public Administration.(In Chinese)[J]Economic Research Journal 2005 40(2):14-17

[8]M,Gareth,Images of Organization .[J] Chinese Public Administration 2015 30(3):40-42 
[9]T.Vinod,The Quality of Growth.[J]Labor and Social Security 2014 21(5):12-14 